\title{
The Measurement of Health Care System Efficiency: Cross-country Comparison by Geographical Region*
}

\author{
Younhee Kim** and Minah Kang****
}

\begin{abstract}
Performance of health care delivery at the cross-country level has not often been directly evaluated by given inputs and outputs. This study estimates the efficiency of the health care systems of 170 countries by extending recent research using Simar and Wilson's bootstrap data envelopment analysis with a sensitivity test. The 170 countries are divided into four groups to compute efficiency estimators necessary to attaining a homogeneity requirement. The major finding is that most countries were inefficient to maximize the use of their inputs at the given output level. Countries in the high-income group have a relatively high average efficiency, but only $16.7 \%$ of the countries performed efficiently in the management of their health care systems. Notably, Asian countries performed more efficiently among other regions in each group. This study suggests that inefficient countries should pay attention to benchmark health care best practices within their regional peer groups.
\end{abstract}

Keywords: bootstrap, data envelopment analysis, efficiency, health care productivity, sensitivity test

\section{INTRODUCTION}

For the past two decades government reform around the world has prioritized to improve productivity for the delivery of services and the operation of organizational capacity. Performance evaluation has become an essential part of the policy decisionmaking process. The linkages between resources and results allow governments to

* This work was supported by the National Research Foundation of Korea Grant funded by the Korean government (NRF-2012S1A3A2033416).

** Younhee Kim is an associate professor of public administration in the Department of Political Science at East Carolina University. E-mail: kimy@ecu.edu.

*** Minah Kang, corresponding author, is an associate professor in the Department of Public Administration at Ewha Womans University. E-mail: minahkang@ewha.ac.kr.

Manuscript received February 10, 2014; out for review February 24, 2014; review completed March 12, 2014; accepted March 14, 2014.

The Korean Journal of Policy Studies, Vol. 29, No. 1 (2014), pp. 21-44.

(C) 2014 by the GSPA, Seoul National University 
develop realistic target goals and to achieve explicit objectives. Similarly, performance measurement has become critical in health care management in the wake of the rapid increase of government expenditures on health care delivery in many countries. Applying straightforward approaches to measure performance could offer useful information that would ensure the fundamental functions of health care systems at the cross-national level.

Despite the importance of efficiency measurements in health care delivery, the conceptualization of health care performance has remained incomplete. Lovell (1993) argues that inefficiency in health care systems is often driven by inappropriate measures of service activities, uncertain objectives, and misidentified units of analysis. Subsequent studies have asserted that the measures of health care delivery seem to be less robust and less routinized in comparison to other fields (e.g., Rehm, Greenfield, \& Rogers, 2001; Spinks \& Hollingsworth, 2009) and remain highly sensitive to different environmental settings (Hollingsworth, 2008).

Data envelopment analysis (DEA) allows an assessment of the productivity of each country's health care system through a comparison of its relative technical efficiency to that of its peer group. Furthermore, identified inefficient countries can use a set of corresponding efficient countries as benchmarks for increasing efficiency in areas where improvements are most needed. A dozen recent studies used DEA to estimate health care efficiency across countries (see table 1), but the input and output measures that they relied on in comparing one country's health care performance to that of others are different from each other. Since applying DEA allows freedom from specification of production function parameters, it is critical to meet minimum requirements, such as ensuring selection of a suitable input-output combination and homogeneity of the comparison group, so as to reduce statistical shortcomings of measurement errors and generalization.

A desirable package of measures for DEA should be complete, decomposable, operational, nonredundant, and minimal (Keeney \& Raiffa, 1993), so a decision for an input-output combination is made by the criteria of exclusivity and exhaustiveness, which means that only outputs correlated with inputs should be included in a model (Thanassoulis, 2001). In general, inputs represent resources used and outputs indicate the utility of achieving objectives (Richards, 2003). Despite a variety of innovative methods for improving DEA techniques, the selection of appropriate inputs and outputs is still considered difficult in the health care areas.

This study estimates the production efficiency of health care systems at the crosscountry level by extending recent empirical research so as to ensure selection of an adequate input and output combination, using a DEA-bootstrapping method. This method, which has not been applied in much research to date, allows one to estimate 
the sampling variation of efficiency estimators using country-level data and thereby measure the sensitivity of health care efficiency scores. A sensitivity test is also conducted to verify the robustness of outputs in this study; this is accomplished by comparing variations in efficiency scores with different subsets of input-output combinations. To satisfy the requirement of homogeneity within a peer group whose production efficiency is being compared, this study clusters the 170 countries into the four income-based groups classified by World Bank, ensuring that each assessment result is more comparable with other units in each group. Achievement of health care system efficiency by geographical regions is compared in order to provide benchmarking information for the implementation of health care sector reform (Hollingsworth \& Wildman, 2003).

\section{PRODUCTIVITY MEASUREMENT IN HEALTH CARE SYSTEMS}

\section{Needs for the Measurement of Health Care Efficiency}

As expenditures for health care have been rapidly increasing in most countries due to a continuous rise in demand for better services and longer life expectancy, many countries have been trying to reform their health care system to improve the efficiency of the delivery of health care to their citizens in a way that is sustainable. These reforms broadly range from improving the quality of health care provisions to developing new financing strategies and new technologies as well as the capacity of the health care workforce. While all the major industrialized countries have spent a considerable proportion of public expenditures on health care, they still fall short when it comes to providing accessible, high-quality, and efficient health care (Schoen, 2007). Fulfilling these goals makes measuring the efficiency of a health care system accurately a priority in health care policy and health management. It stands to reason that if a country's health services were explicitly evaluated by target objectives and valid measures, the government could develop strategies for remedying its weaknesses in providing health care services.

The efficiency of health care systems may be gauged differently by diverse stakeholders (e.g., providers, purchasers, consumers, policy makers, society) and measured by an equally broad base of evaluators (e.g., individuals, hospitals, local and national governments). Despite this wide variety of definitions and measures, a generally accepted concept of efficiency, computed by a given combination of inputs and outputs, could be applied to evaluate the productivity of health care systems. A well-known example of such an approach is the international assessment of the health system 
conducted by World Health Organization (WHO) in 2000. This assessment paid special attention to the objectives of national health care systems and evaluations of efficiency, which stimulated global interest in measuring inputs and outcomes of health care systems. The report highlighted that the responsibility of government is substantial in achieving better health system performance through formulating and implementing such objectives (WHO, 2000).

Health care systems are sufficiently different at the cross-country level (Jung, 2003) that productivity comparison in health care delivery with respect to particular health care resources (e.g., number of annual inpatients and outpatients, health workers, patient beds, staffed beds) may serve to measure hospital efficiency but cannot provide a complete picture of the overall performance at the national level. A national health system should be evaluated by focusing on the capacities of the health system that can be commonly compared. Such an approach can improve health status by making data accessible across countries and thus may lead to a streamlined and realistic national health policy.

\section{Efficiency Analysis in Health Care}

DEA is a nonparametric linear estimation that is relatively free of the restrictive production functions of traditional parametric inference but that still requires one to make minimal assumptions about a functional form of frontiers if one is to evaluate the relative efficiency of a set of individual units (Charnes, Cooper, \& Rhodes, 1981). Farrell (1957) first introduced the measures of efficiency by combining relevant inputs and outputs, which are determined by the ratio of the prices of the inputs and outputs. Recent discussions of DEA efficiency measures have suggested that one will secure the best ratio of inputs and outputs by satisfying certain conditions, such as using positive input and output scores, ranging the resulting ratio between zero and unity, and applying the same weight to all decision units (Cooper, Seiford, \& Tone, 2007). DEA is a straightforward approach to assessing an efficiency gap between the best productive practices and other inefficient practices in a group because it allows researchers to use multiple inputs and outputs simultaneously, enabling them to calculate the relative efficiency of each unit and to compare one unit directly with its peer group. An efficiency score derived from DEA provides information as to how well an individual unit is doing compared to its peer group.

The original DEA approach proposed by Charnes, Cooper, and Rhodes (hereafter CCR) (1978) is built on the assumption of constant returns to scale (CRS), which suggests the production function in the single input-single output case should be specified at an optimal point. Jacobs, Smith, and Street (2006) noted that health care systems 
mainly operate at an inefficient scale due to various constraints and imperfect competition, so alternative DEA models have been proposed to relax the CRS assumption. Banker, Charnes, and Cooper (hereafter BCC) (1984) extended the CCR approach, developing a model to accommodate a more flexible assumption of variable returns to scale (VRS), which has become the standard analytical formulation of DEA using the multiple input-multiple output approach. The BCC model offers two separate analyses to identify returns to scale at a point on the VRS frontier: the first evaluates technical efficiency using an envelopment model and the second evaluates returns to scale efficiency. As a result, the BCC model improves the generality of the DEA approach, handling multiple outputs and inputs simultaneously (Cooper et al., 2007).

The production function approach described by Evans, Murray, and Lauer (2000) suggests that three types of variables could be used to measure efficiency. These are relevant health system inputs, an appropriate outcome indicator, and determinants of health that come from outside the health system. In the health care research literature, outputs are largely indicated by life expectancy and infant mortality, while inputs are typically measured by monetary and personnel resources such as health expenditures and the size of the health workforce.

The health-system inputs, which are expected to produce a defined output, usually refer to the quantities of labor and financial capacities, whereas the non-health inputs are denoted by reference to educational and income levels. Greene (2004) noted that health expenditures are the most predominant input factor in evaluations of the productivity of health care programs. Some studies have incorporated labor-related inputs (e.g., doctors, nurses) into their DEA formulation using an international dataset (e.g., Afonso \& St. Aubyn, 2005; Bhat, 2005; Grosskopf, Lindgren, \& Poullier, 2006; Retzlaff-Roberts, Chang, \& Rubin, 2004) because adding labor-related inputs may lead to a parsimonious DEA model at an organizational level (Jacobs et al., 2006). Labor indicators are, however, neither commonly available across countries nor accurately measured, and so labor inputs cannot be strictly used on a comparable basis. Desirable health care outcomes are not simply the product of effective health care services. Rather, the health status of a population may be also a result of various social, cultural, and environmental factors, such as the educational level achieved by mothers.

Along the same lines, "changes in life expectancy at good health caused by health services" may be a relevant output, but its concept is hard to measure (Färe et al., 1997, p. 361). Therefore, Färe et al. (1997) used the infant mortality rate and women's life expectancy at age 40 as the countermeasures of the changes in life expectancy. Unlike other studies, Grosskopf et al. (2006) used the under-five child mortality rate as an output, on the grounds that infant mortality is not a challenging issue in highincome or developed countries. Table 1 presents measures of inputs and outputs used 
Table 1. Efficiency Measures of Health Care Systems

\begin{tabular}{|c|c|c|c|}
\hline Author(s) & Input & Output & Unit \\
\hline $\begin{array}{l}\text { Adam et al. } \\
\text { (2011) }\end{array}$ & - public spending on health & $\begin{array}{l}\text { - life expectancy at birth } \\
\text { - infant mortality rate }\end{array}$ & $\begin{array}{l}19 \text { OECD } \\
\text { countries }\end{array}$ \\
\hline $\begin{array}{l}\text { Afonso \& Aubyn } \\
\text { (2005) }\end{array}$ & $\begin{array}{l}\cdot \text { number of doctors } \\
\text { - number of nurses } \\
\text { - number of patient beds per } \\
1000\end{array}$ & $\begin{array}{l}\text { - life expectancy } \\
\text { - infant survival rate }\end{array}$ & $\begin{array}{l}24 \text { OECD } \\
\text { countries }\end{array}$ \\
\hline $\begin{array}{l}\text { Alexander et al. } \\
\text { (2003) }\end{array}$ & $\begin{array}{l}\text { - health care expenditure per } \\
\text { capita }\end{array}$ & $\begin{array}{l}\text { - male-disability-adjusted } \\
\text { life expectancy } \\
\text { - female-disability-adjusted } \\
\text { life expectancy } \\
\text { - infant mortality rate } \\
\text { subtracted from } 1000\end{array}$ & $\begin{array}{l}51 \text { developing } \\
\text { countries }\end{array}$ \\
\hline Bhat (2005) & $\begin{array}{l}\text { - } \text { number of practicing } \\
\text { physicians } \\
\text { - number of inpatient beds } \\
\text { - pharmaceutical consumption }\end{array}$ & $\begin{array}{l}\text { - population aged } 0-19 \text { years } \\
\text { - population aged } 20-64 \\
\text { - population } 65 \text { and older }\end{array}$ & $\begin{array}{l}24 \text { OECD } \\
\text { countries }\end{array}$ \\
\hline $\begin{array}{l}\text { González et al. } \\
(2010)\end{array}$ & $\begin{array}{l}\text { - total expenditure in health } \\
\text { care in purchasing power } \\
\text { parity of \$US per capita } \\
\text { - school-life expectancy }\end{array}$ & $\begin{array}{l}\text { - health life expectancy } \\
\text { - disability adjusted life years }\end{array}$ & $\begin{array}{l}165 \text { countries } \\
\text { divided into the } \\
\text { four income } \\
\text { groups }\end{array}$ \\
\hline Greene (2004) & $\begin{array}{l}\text { - public and private health } \\
\text { care expenditure per capita } \\
\text { - average years of education }\end{array}$ & $\begin{array}{l}\text { - disability-adjusted life } \\
\text { expectancy } \\
\text { - a composite measure of } \\
\text { health care delivery }\end{array}$ & $\begin{array}{l}191 \text { countries } \\
\text { (OECD vs. } \\
\text { non-OECD) }\end{array}$ \\
\hline $\begin{array}{l}\text { Grosskopf et al. } \\
\text { (2006) }\end{array}$ & $\begin{array}{l}\text { - public health care } \\
\text { expenditure as \% of per } \\
\text { capita GDP } \\
\text { - private health care } \\
\text { expenditure as \% of per } \\
\text { capita GDP } \\
\text { - gross capital formation per } \\
\text { capita } \\
\text { - labor force per capita } \\
\text { - enrollment rate in primary } \\
\text { education }\end{array}$ & $\begin{array}{l}\text { - life expectancy at birth } \\
\text { - reciprocal of the under } 5 \\
\text { mortality rate } \\
\text { - GDP per capita }\end{array}$ & 143 countries \\
\hline $\begin{array}{l}\text { Hollingsworth \& } \\
\text { Wildman (2003) }\end{array}$ & $\begin{array}{l}\text { - health care expenditure per } \\
\text { capita } \\
\text { - schooling }\end{array}$ & $\begin{array}{l}\text { - disability-adjusted life } \\
\text { expectancy }\end{array}$ & $\begin{array}{l}140 \text { countries } \\
\text { (OECD vs. } \\
\text { non-OECD) }\end{array}$ \\
\hline $\begin{array}{l}\text { Retzlaff-Roberts } \\
\text { et al. (2004) }\end{array}$ & $\begin{array}{l}\cdot \text { number of beds per } 1000 \\
\text { - MRI per million } \\
\text { - number of physicians per } \\
1000 \\
\text { - health expenditure per capita }\end{array}$ & $\begin{array}{l}\text { - infant mortality } \\
\text { - life expectancy at birth }\end{array}$ & $\begin{array}{l}27 \text { OECD } \\
\text { countries }\end{array}$ \\
\hline $\begin{array}{l}\text { Spinks \& } \\
\text { Hollingsworth } \\
(2005,2009)\end{array}$ & $\begin{array}{l}\text { - school expectancy years } \\
\text { - unemployment rates } \\
\text { - GDP per capita } \\
\text { - total health care expenditure } \\
\text { per capita }\end{array}$ & - life expectancy at birth & $\begin{array}{l}28 \text { OECD } \\
\text { countries }\end{array}$ \\
\hline
\end{tabular}


in recent studies that conduct cross-country analysis of health care efficiency.

There have been mixed results on the relationship between income levels and health outcomes (e.g., mortality, life expectancy) at the country level. Studies using data dating prior to the mid-1990s mostly asserted significant associations between income and health status (e.g., Evans et al., 2000; Greene, 2004; Wilkinson, 1992), whereas several recent data found weak or no relationships between the variables (e.g., Berger \& Messer, 2002; Musgrove, 1996).

\section{DATA AND METHOD}

\section{Data}

Data were obtained from the World Bank's Development Indicators \& Global Development Finance in 2007, which includes the 244 countries. Due to a missing data issue, this study uses the 170 countries to estimate health care efficiency. Previous research commonly divided these countries into two groups - for example, those belonging to the Organization for Economic Co-operation and Development (OECD) and those not (e.g., Greene, 2004; Hollingsworth \& Wildman, 2003). But different social conditions and income levels the 137 non-OECD countries may mean they are not homogeneous enough to be considered as a relatively comparable group for estimating efficiency scores. Hollingsworth and Wildman (2003) suggested further stratifying both OECD and non-OECD countries by gross domestic product or geographical region.

For this reason, this study used the four income-based groups classified by World Bank to fulfill the minimum requirement of homogeneity across units in the DEA analysis. These income groups-low income $(\$ 1,025$ or less); lower middle income (\$1,026-\$4,035); upper middle income $(\$ 4,036-\$ 12,475)$; and high income $(\$ 12,476$ or more)—are defined by gross national income per capita in U.S. dollars using the World Bank Atlas conversion factor. Each group includes more than 30 units (i.e., 42 countries in the high income, 45 countries in the upper middle income, 51 countries in the lower middle income, 32 countries in the low income group) that satisfy the minimum number of units for achieving a reasonable level of discrimination across different groups.

\section{Input and Output Measures}

As Golany and Roll (1989) have noted, it is hard to determine the adequacy of inputoutput combinations to assess a unit's performance. Judgmental, correlational, and 
trial processes can be conducted to further specify suitable input-output relationships. A DEA formulation utilized in this study was defined by the straightforward classification of the determinants and the discriminating power of decision-making units (DMUs) after running a series of combinations of the initial factors. The quality of a DEA model is often judged by the discriminating power between DMUs; the more input and output variables used in a model, the less discriminating power of the model (Jacobs et al., 2006). Thus, there should be at least three times as many DMUs as input and output variables.

One way to identify a relevant combination of input and output variables is to omit one variable in order to evaluate discriminatory power of the units and to eliminate redundancy by other factors. However, Dyson et al. (2001) found that dropping one highly correlated variable often decreased the efficiency measurement significantly. Thus, omitting variables only based on correlation may not be the best approach except in a perfect correlation case. None of the proposed inputs and outputs in this study are not so highly correlated with each other as to be considered as a redundant variable, so this study retains all input and output measures in estimating the efficiency of public health care delivery in each country.

At the system level of health care, the health status of the population may depend not only on the nation's health expenditure level but also on various aspects of the social environment (Grossman \& Kaestner, 2004; González, Cárcaba, \& Ventura, 2010). The inputs should thus include a financial component as well as a social environment component. This study used public health expenditures, represented as a percentage of the government expenditure on health care in 2007 U.S. dollars, as a proxy measure of financial resources. The second input, schooling, is measured by the expected average years of schooling for women over 15 in each country, since women's education is one of the most important factors when it comes to what kind of access to health care children get (Gonzálezet al., 2010), especially for reduction in child mortality (Desai \& Alva, 1998; Sen, 1999).

The outputs in this study are life expectancy at birth and the child mortality rate of children under five. Life expectancy is considered a relevant indicator of life conditions in the long run (Evans, Murray, \& Lauer, 2001). Life expectancy at birth is measured by the average human lifespan of population in the country. The second output, the child mortality rate of children under five, is considered a legitimate way of indicating significant differences in health outcomes across countries (Grubaugh \& Santerre, 1994). Child mortality is known to be a sensitive measure for evaluating the effectiveness of government interventions, such as access to clean water and sanitation, prenatal and postnatal care services, female education, and nutrition (Sen, 1999).

To understand and compare geographical differences of health care system effi- 
ciency, the results of this study are presented by regions. Table 2 summarizes the descriptive statistics of the input measures. The average proportion of public health expenditure in relation to total government expenditure varies across four income

Table 2. Summary Statistics of Inputs

\begin{tabular}{|c|c|c|c|c|c|c|c|}
\hline Input & Group & Region & Obs. & Mean & Std. Dev. & Min & Max \\
\hline \multirow{4}{*}{$\begin{array}{l}\text { Public Health } \\
\text { Expenditure } \\
(\%)\end{array}$} & High Income & $\begin{array}{l}\text { Africa } \\
\text { Asia } \\
\text { Europe } \\
\text { North America } \\
\text { Oceania }\end{array}$ & $\begin{array}{r}1 \\
9 \\
26 \\
4 \\
2\end{array}$ & $\begin{array}{c}7 \\
9.6 \\
14.2 \\
14.5 \\
17.7\end{array}$ & $\begin{array}{r}3.8 \\
2.9 \\
4.1 \\
.9\end{array}$ & $\begin{array}{r}7 \\
5.6 \\
5.8 \\
9.8 \\
17.1\end{array}$ & $\begin{array}{c}7 \\
17.9 \\
20.0 \\
18.7 \\
18.3\end{array}$ \\
\hline & $\begin{array}{l}\text { Upper-Middle } \\
\text { Income }\end{array}$ & $\begin{array}{l}\text { Africa } \\
\text { Asia } \\
\text { Europe } \\
\text { North America } \\
\text { South America }\end{array}$ & $\begin{array}{r}9 \\
8 \\
13 \\
7 \\
8\end{array}$ & $\begin{array}{l}10.6 \\
10.9 \\
11.0 \\
14.6 \\
13.3\end{array}$ & $\begin{array}{l}2.7 \\
3.1 \\
3.1 \\
7.8 \\
3.9\end{array}$ & $\begin{array}{l}8.3 \\
7.2 \\
3.7 \\
5.6 \\
6.1\end{array}$ & $\begin{array}{l}16.7 \\
16.1 \\
15.1 \\
30.6 \\
17.9\end{array}$ \\
\hline & $\begin{array}{l}\text { Lower-Middle } \\
\text { Income }\end{array}$ & $\begin{array}{l}\text { Africa } \\
\text { Asia } \\
\text { Europe } \\
\text { North America } \\
\text { Oceania } \\
\text { South America }\end{array}$ & $\begin{array}{r}17 \\
18 \\
2 \\
5 \\
6 \\
3\end{array}$ & $\begin{array}{r}8.6 \\
7.3 \\
11.4 \\
14.3 \\
15.0 \\
11.4\end{array}$ & $\begin{array}{l}2.8 \\
3.8 \\
3.9 \\
2.5 \\
3.6 \\
3.6\end{array}$ & $\begin{array}{r}4.4 \\
3.1 \\
8.6 \\
12.2 \\
9.3 \\
7.4\end{array}$ & $\begin{array}{l}13.9 \\
19.2 \\
14.1 \\
17.9 \\
20.1 \\
14.5\end{array}$ \\
\hline & Low Income & $\begin{array}{l}\text { Africa } \\
\text { Asia } \\
\text { North America }\end{array}$ & $\begin{array}{r}24 \\
7 \\
1\end{array}$ & $\begin{array}{r}11.1 \\
6.9 \\
9.5\end{array}$ & $\begin{array}{c}4.6 \\
3.7 \\
.\end{array}$ & $\begin{array}{l}3.1 \\
0.8 \\
9.5\end{array}$ & $\begin{array}{r}18.1 \\
11.7 \\
9.5\end{array}$ \\
\hline \multirow{4}{*}{ Schooling } & High Income & $\begin{array}{l}\text { Africa } \\
\text { Asia } \\
\text { Europe } \\
\text { North America } \\
\text { Oceania }\end{array}$ & $\begin{array}{r}1 \\
9 \\
26 \\
4 \\
2\end{array}$ & $\begin{array}{r}4.5 \\
7.9 \\
11.6 \\
12.1 \\
11.9\end{array}$ & $\begin{array}{l}2.6 \\
1.3 \\
2.2 \\
0.8\end{array}$ & $\begin{array}{r}4.5 \\
5.0 \\
7.7 \\
9.7 \\
11.5\end{array}$ & $\begin{array}{r}4.5 \\
12.2 \\
13.6 \\
14.2 \\
12.3\end{array}$ \\
\hline & $\begin{array}{l}\text { Upper-Middle } \\
\text { Income }\end{array}$ & $\begin{array}{l}\text { Africa } \\
\text { Asia } \\
\text { Europe } \\
\text { North America } \\
\text { South America }\end{array}$ & $\begin{array}{r}9 \\
8 \\
13 \\
7 \\
8\end{array}$ & $\begin{array}{r}7.1 \\
7.3 \\
10.6 \\
9.5 \\
8.5\end{array}$ & $\begin{array}{l}2.3 \\
2.6 \\
2.1 \\
1.6 \\
1.5\end{array}$ & $\begin{array}{l}4.2 \\
3.4 \\
5.8 \\
7.6 \\
6.4\end{array}$ & $\begin{array}{l}11.7 \\
11.9 \\
12.9 \\
12.2 \\
10.1\end{array}$ \\
\hline & $\begin{array}{l}\text { Lower-Middle } \\
\text { Income }\end{array}$ & $\begin{array}{l}\text { Africa } \\
\text { Asia } \\
\text { Europe } \\
\text { North America } \\
\text { Oceania } \\
\text { South America }\end{array}$ & $\begin{array}{r}17 \\
18 \\
2 \\
5 \\
6 \\
3\end{array}$ & $\begin{array}{r}4.0 \\
6.6 \\
11.7 \\
6.0 \\
8.8 \\
7.8\end{array}$ & $\begin{array}{l}2.0 \\
3.8 \\
0.7 \\
1.6 \\
2.8 \\
1.4\end{array}$ & $\begin{array}{r}1.5 \\
0.7 \\
11.2 \\
3.9 \\
5.0 \\
6.7\end{array}$ & $\begin{array}{r}8.4 \\
12.5 \\
12.2 \\
8.3 \\
12.0 \\
9.4\end{array}$ \\
\hline & Low Income & $\begin{array}{l}\text { Africa } \\
\text { Asia } \\
\text { North America }\end{array}$ & $\begin{array}{r}24 \\
7 \\
1\end{array}$ & $\begin{array}{l}2.3 \\
4.8 \\
3.4\end{array}$ & $\begin{array}{c}1.4 \\
4.4 \\
.\end{array}$ & $\begin{array}{l}0.6 \\
0.4 \\
3.4\end{array}$ & $\begin{array}{r}5.9 \\
11.4 \\
3.4\end{array}$ \\
\hline
\end{tabular}


Table 3. Summary Statistics of Outputs

\begin{tabular}{|c|c|c|c|c|c|c|c|}
\hline Output & Group & Region & Obs. & Mean & Std. Dev. & Min & Max \\
\hline \multirow{4}{*}{$\begin{array}{l}\text { Life } \\
\text { Expectancy }\end{array}$} & High Income & $\begin{array}{l}\text { Africa } \\
\text { Asia } \\
\text { Europe } \\
\text { North America } \\
\text { Oceania }\end{array}$ & $\begin{array}{r}1 \\
9 \\
26 \\
4 \\
2\end{array}$ & $\begin{array}{l}50.6 \\
78.0 \\
79.2 \\
75.9 \\
80.9\end{array}$ & $\begin{array}{l}3.0 \\
2.3 \\
5.2 \\
0.9\end{array}$ & $\begin{array}{l}50.6 \\
73.4 \\
73.9 \\
69.6 \\
80.3\end{array}$ & $\begin{array}{l}50.6 \\
82.9 \\
82.0 \\
81.2 \\
81.5\end{array}$ \\
\hline & $\begin{array}{l}\text { Upper-Middle } \\
\text { Income }\end{array}$ & $\begin{array}{l}\text { Africa } \\
\text { Asia } \\
\text { Europe } \\
\text { North America } \\
\text { South America }\end{array}$ & $\begin{array}{r}9 \\
8 \\
13 \\
7 \\
8\end{array}$ & $\begin{array}{l}66.4 \\
71.8 \\
73.0 \\
74.6 \\
74.1 \\
\end{array}$ & $\begin{array}{l}9.2 \\
2.1 \\
2.2 \\
3.8 \\
2.8\end{array}$ & $\begin{array}{l}51.6 \\
68.4 \\
68.9 \\
68.7 \\
69.2\end{array}$ & $\begin{array}{l}75.3 \\
74.6 \\
76.8 \\
79.0 \\
78.7\end{array}$ \\
\hline & $\begin{array}{l}\text { Lower-Middle } \\
\text { Income }\end{array}$ & $\begin{array}{l}\text { Africa } \\
\text { Asia } \\
\text { Europe } \\
\text { North America } \\
\text { Oceania } \\
\text { South America }\end{array}$ & $\begin{array}{r}17 \\
18 \\
2 \\
5 \\
6 \\
3\end{array}$ & $\begin{array}{l}56.5 \\
68.4 \\
68.9 \\
72.9 \\
69.8 \\
68.6\end{array}$ & $\begin{array}{l}8.8 \\
4.4 \\
0.4 \\
2.3 \\
2.1 \\
3.2\end{array}$ & $\begin{array}{l}45.4 \\
61.4 \\
68.6 \\
70.6 \\
66.7 \\
66.0\end{array}$ & $\begin{array}{l}71.6 \\
74.6 \\
69.2 \\
76.6 \\
72.0 \\
72.1\end{array}$ \\
\hline & Low Income & $\begin{array}{l}\text { Africa } \\
\text { Asia } \\
\text { North America }\end{array}$ & $\begin{array}{r}24 \\
7 \\
1\end{array}$ & $\begin{array}{l}54.3 \\
62.2 \\
61.4\end{array}$ & $\begin{array}{c}5.4 \\
8.3 \\
.\end{array}$ & $\begin{array}{l}47.3 \\
44.3 \\
61.4\end{array}$ & $\begin{array}{l}65.8 \\
67.1 \\
61.4\end{array}$ \\
\hline \multirow{4}{*}{$\begin{array}{l}\text { Child } \\
\text { Mortality } \\
\text { under Age } 5\end{array}$} & High Income & $\begin{array}{l}\text { Africa } \\
\text { Asia } \\
\text { Europe } \\
\text { North America } \\
\text { Oceania }\end{array}$ & $\begin{array}{r}1 \\
9 \\
26 \\
4 \\
2\end{array}$ & $\begin{array}{r}149.9 \\
9.9 \\
4.8 \\
15.9 \\
5.8\end{array}$ & $\begin{array}{r}5.8 \\
1.2 \\
13.4 \\
0.7\end{array}$ & $\begin{array}{r}149.9 \\
2.8 \\
3.2 \\
6.1 \\
5.3\end{array}$ & $\begin{array}{r}149.9 \\
21.4 \\
7.6 \\
35.3 \\
6.3\end{array}$ \\
\hline & $\begin{array}{l}\text { Upper-Middle } \\
\text { Income }\end{array}$ & $\begin{array}{l}\text { Africa } \\
\text { Asia } \\
\text { Europe } \\
\text { North America } \\
\text { South America }\end{array}$ & $\begin{array}{r}9 \\
8 \\
13 \\
7 \\
8\end{array}$ & $\begin{array}{l}40.7 \\
20.9 \\
15.1 \\
19.6 \\
19.2\end{array}$ & $\begin{array}{r}23.3 \\
9.3 \\
8.5 \\
10.3 \\
6.3\end{array}$ & $\begin{array}{r}12.6 \\
6.8 \\
7.3 \\
6.3 \\
8.8\end{array}$ & $\begin{array}{l}72.8 \\
34.0 \\
39.3 \\
33.4 \\
28.5\end{array}$ \\
\hline & $\begin{array}{l}\text { Lower-Middle } \\
\text { Income }\end{array}$ & $\begin{array}{l}\text { Africa } \\
\text { Asia } \\
\text { Europe } \\
\text { North America } \\
\text { Oceania } \\
\text { South America }\end{array}$ & $\begin{array}{r}17 \\
18 \\
2 \\
5 \\
6 \\
3\end{array}$ & $\begin{array}{r}102.2 \\
46.7 \\
17.1 \\
28.2 \\
25.7 \\
39.6\end{array}$ & $\begin{array}{r}43.0 \\
21.5 \\
1.6 \\
9.2 \\
8.7 \\
16.8\end{array}$ & $\begin{array}{l}25.1 \\
15.9 \\
15.9 \\
19.4 \\
17.9 \\
24.1\end{array}$ & $\begin{array}{r}170.8 \\
91.2 \\
18.2 \\
41.5 \\
36.1 \\
57.5\end{array}$ \\
\hline & Low Income & $\begin{array}{l}\text { Africa } \\
\text { Asia } \\
\text { North America }\end{array}$ & $\begin{array}{r}24 \\
7 \\
1\end{array}$ & $\begin{array}{r}141.1 \\
84.1 \\
92.0\end{array}$ & $\begin{array}{c}43.5 \\
55.9 \\
.\end{array}$ & $\begin{array}{l}61.3 \\
39.4 \\
92.0\end{array}$ & $\begin{array}{r}209.0 \\
203.5 \\
92.0\end{array}$ \\
\hline
\end{tabular}

groups and regions. In general, African and Asian countries in high- and lower-middleincome groups spend less on public health than other countries. The average number of years of schooling in African and Asian countries is substantially lower than among 
the other groups.

There are substantial differences across not only groups but also regions within each group with respect to both outputs (see table 3). Countries in the low-income group have the lowest level of life expectancy, averaging 56.2 years. A noticeable result finds that the average mortality rate for children under five in high-income countries is 12.2 times lower than those in low-income countries. African and Asian countries performed poorly with reference to both indicators.

One issue in our DEA model that we had to confront is a reverse output that contradicts the assumption of the isotonic relationship between inputs and outputs. Previous studies have suggested several ways of handling anti-isotonic factors so as to incorporate them in the application of DEA, which are to invert the anti-isotonic factor, subtract the value of the undesirable factor from a large number of the output (Dyson et al., 2001), generate a new nonseparating measure, or compute the weight vector (Scheel, 2001). This study used reverse scoring, the most commonly adapted approach, to incorporate reverse quantities into the model, as suggested by Lewis and Sexton (2004) and Ozbek, de la Garza, and Triantis (2010). The way to transform the nonisotonic value $Z_{j}$ into the inverse quantity $Z_{j}{ }_{j}$ is to subtract the reverse value $Z_{j}$ from $M$, where $M>\max _{p}\left(Z_{p}\right), p$ is a dummy index. The value of $M$ denotes $\max _{p}\left(Z_{p}\right)+1$ (see Lewis \& Sexton, 2004). This study inverted the mortality rate of children under age five by subtracting a reverse value from a large number of the output and then adding one to the formulation in order to confirm that all reversed values are positive.

\section{DEA Bootstrap Specification with Sensitivity Tests}

A series of sensitivity tests has been introduced to verify efficiency stability of basic DEA models that researchers have modified by changing data size and input-output combinations (e.g., Charnes et al,. 1985; Seiford \& Zhu, 1998a, 1998b; Thompson et al., 1996). Studies noted that transforming reverse data may result in changes to the efficiency scores of units (e.g., Dyson et al., 2001; Scheel, 2001), so a way of testing how stable the efficiency is across units is needed. Utilizing sensitivity tests allows this study to specify the impact of the reverse output and to validate the robustness of the model specifications through an assessment of a discriminatory power of each measure. Although no clear action is suggested in a case of DEA applications for a reversing relationship, this study used two techniques to test the stability of the original model.

The first technique was bootstrapping. Through extensive resampling from an original sample, bootstrapping of nonparametric efficiency estimates allows correction of problems inherent in traditional DEA techniques (Simar \& Wilson, 1999, 2000). The DEA-bootstrap method is based on a data-generating process that incorporates 
random deviations from the original data whose purpose is to analyze the sensitivity of efficiency scores to sampling variation. The original bootstrap, however, was criticized due to the possibility that it might provide a poor estimate of the data-generating process. Simar and Wilson $(1998,2000)$ proposed a kernel smoothing method to estimate original densities of technical efficiency scores derived from nonparametric frontier techniques, which is a more popular bootstrapping method, especially with cross-sectional data. This study used Simar and Wilson's bootstrap algorithm to estimate bias-corrected DEA efficiency scores, using LIMDEP 9.0 with 100 replications. Usually, 50 or 100 replications are considered sufficient (Greene, 2007).

Second, three models were run separately to confirm proportional changes in efficient DMUs using different subsets of the input-output combinations. The first run served as a reference specification and included the full set of inputs and outputs. The second and the third run used each output with two inputs. By describing the variations in efficiency scores of DMUs compared with other specifications, this study is thus able to interpret the robustness of our full model.

\section{RESULTS}

A summary of the bootstrap efficiency scores for the four groups is presented in table 4. The number of efficient countries in each model is similar across the four groups, and the variances in the average efficiency scores are not relatively different across the groups, with a few exceptions in the upper-middle-income group. On average, the full model presents the highest efficiency in the both high- and upper-middleincome groups. This is not an unexpected result, since the more variables in a model, the better one is able to capture multiple dimensions of overall productivity in health care systems. If the variations among average efficiency scores across specifications do not fundamentally change the results, a complete specification is considered to be robust (Valdmanis, 1992). The original specification in this study turns quite stable efficient countries into inefficient countries. However, life expectancy may hold a discriminate power in the evaluation of health care systems for the upper-middleincome group, since the efficiency scores without the output are fairly different from those of the full model.

The average bootstrap efficiency score of the high-income group in the full model is about $74 \%$, thus yielding an average inefficiency score of $26 \%$. This indicates that the inputs for health care services would have to be reduced by a further $26 \%$ to match the given outputs. On average, countries in the upper-middle-income group need to reduce their inputs by about $23 \%$, while countries in the lower middle and the low 
Table 4. Average Corrected Efficiency Scores by Regions

\begin{tabular}{|c|c|c|c|c|c|c|}
\hline Group & Region & Obs. & $\begin{array}{l}\text { Number of } \\
\text { Frontiers in } \\
\text { Full Model }\end{array}$ & $\begin{array}{l}\text { Full } \\
\text { Model }\end{array}$ & $\begin{array}{c}\text { Life } \\
\text { Expectancy } \\
\text { Excluded }\end{array}$ & $\begin{array}{c}\text { Child } \\
\text { Mortality } \\
\text { Excluded }\end{array}$ \\
\hline High Income & $\begin{array}{l}\text { Africa } \\
\text { Asia } \\
\text { Europe } \\
\text { North America } \\
\text { Oceania }\end{array}$ & $\begin{array}{r}1 \\
9 \\
26 \\
4 \\
2\end{array}$ & $\begin{array}{l}1 \\
4 \\
2 \\
0 \\
0\end{array}$ & $\begin{array}{c}1 \\
.8678 \\
.7118 \\
.4944 \\
.6161\end{array}$ & $\begin{array}{c}1 \\
.8095 \\
.6497 \\
.4651 \\
.4870\end{array}$ & $\begin{array}{c}1 \\
.8742 \\
.6526 \\
.5285 \\
.6358\end{array}$ \\
\hline \multicolumn{4}{|c|}{ Average } & .7380 & .6670 & .7382 \\
\hline Upper-Middle Income & $\begin{array}{l}\text { Africa } \\
\text { Asia } \\
\text { Europe } \\
\text { North America } \\
\text { South America }\end{array}$ & $\begin{array}{r}9 \\
8 \\
13 \\
7 \\
8\end{array}$ & $\begin{array}{l}2 \\
2 \\
3 \\
2 \\
2\end{array}$ & $\begin{array}{l}.8046 \\
.7184 \\
.7256 \\
.8431 \\
.7745\end{array}$ & $\begin{array}{l}.8466 \\
.7429 \\
.6510 \\
.7103 \\
.6063\end{array}$ & $\begin{array}{l}.8141 \\
.7071 \\
.6888 \\
.8388 \\
.7853\end{array}$ \\
\hline \multicolumn{4}{|c|}{ Average } & .7732 & .7114 & .7662 \\
\hline Lower-Middle Income & $\begin{array}{l}\text { Africa } \\
\text { Asia } \\
\text { Europe } \\
\text { North America } \\
\text { Oceania } \\
\text { South America }\end{array}$ & $\begin{array}{r}17 \\
18 \\
2 \\
5 \\
6 \\
3\end{array}$ & $\begin{array}{l}2 \\
5 \\
1 \\
2 \\
1 \\
0\end{array}$ & $\begin{array}{l}.5857 \\
.6907 \\
.7609 \\
.9111 \\
.5962 \\
.4923\end{array}$ & $\begin{array}{l}.7109 \\
.6600 \\
.7616 \\
.8193 \\
.5987 \\
.5006\end{array}$ & $\begin{array}{l}.5738 \\
.6734 \\
.3064 \\
.8276 \\
.3705 \\
.4155\end{array}$ \\
\hline \multicolumn{4}{|c|}{ Average } & .6728 & .6752 & .5279 \\
\hline Low Income & $\begin{array}{l}\text { Africa } \\
\text { Asia } \\
\text { North America }\end{array}$ & $\begin{array}{r}24 \\
7 \\
1\end{array}$ & $\begin{array}{l}4 \\
6 \\
0\end{array}$ & $\begin{array}{l}.5908 \\
.9284 \\
.4703 \\
\end{array}$ & $\begin{array}{l}.6524 \\
.7497 \\
.4339 \\
\end{array}$ & $\begin{array}{l}.6043 \\
.9406 \\
.5512 \\
\end{array}$ \\
\hline \multicolumn{4}{|c|}{ Average } & .6632 & .6120 & .6987 \\
\hline
\end{tabular}

income groups should decrease their input levels by more than $34 \%$ in order to improve health system efficiency. Countries in lower-middle and low-income groups present more variations in efficiency scores than higher income groups (see figure 1). Although direct comparisons of the efficiency scores are not applicable across the four groups, a positive relationship between income and efficiency on average is predicted by these results, as suggested by Greene (2004).

In the high-income group, the corrected efficiency of health care systems is distinctively different by regions, especially for North America. Countries in Asia and Europe are more efficient than those in North America and Oceania. The majority of the OECD countries did not maximize the usability of the inputs to produce decent levels of the outputs. Seven (i.e., Equatorial Guinea, Japan, Kuwait, Oman, Singapore, Cyprus, Israel) of the 42 high-income countries were on the bootstrap efficiency frontier, while 13 countries scored below $60 \%$ of the corrected efficiency, showing a considerably 
Figure 1. A Box Plot of Average Efficiency by Regions and Groups

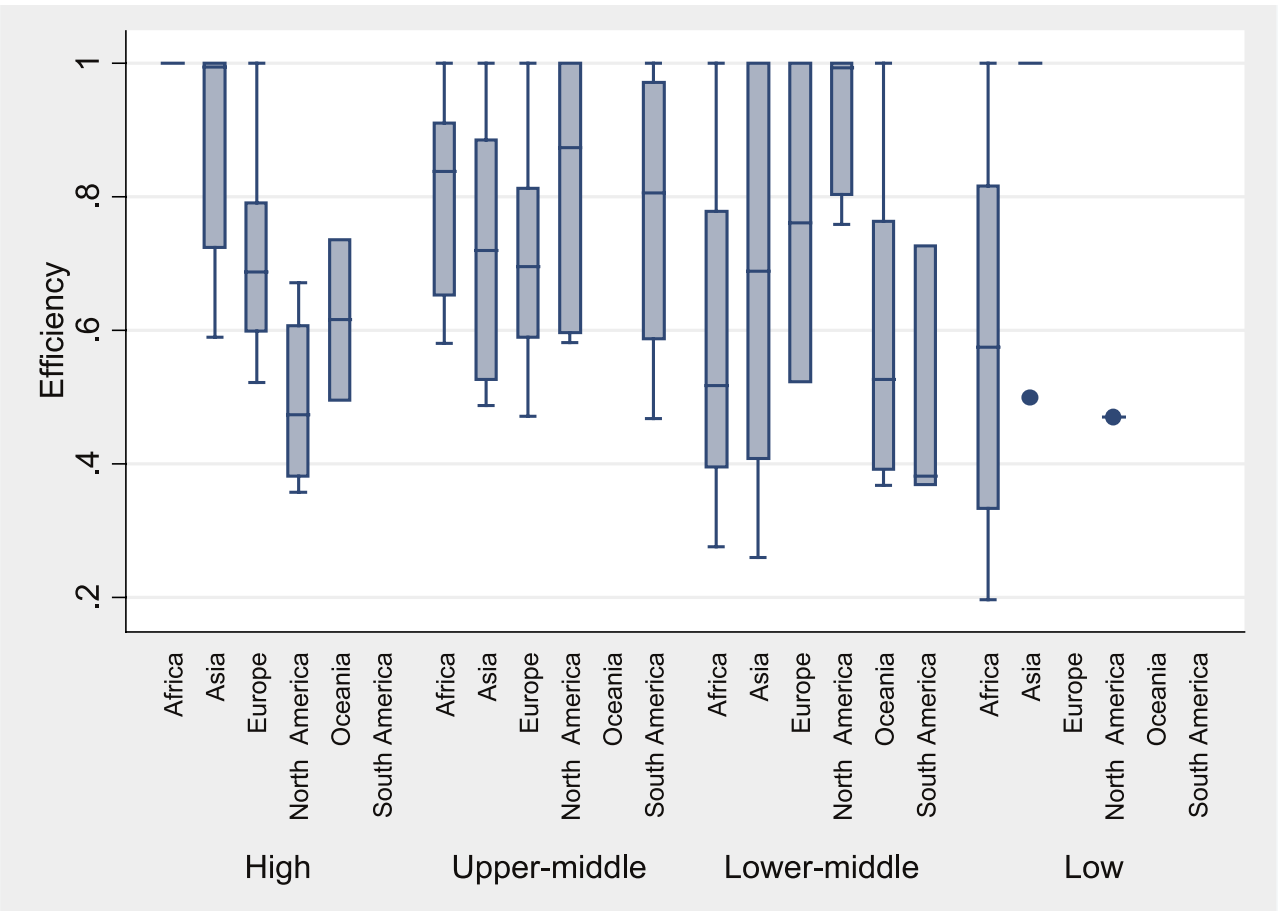

larger gap between the lowest of .3581 and the highest of 1 (see appendix 1).

Countries in Asia are generally more efficient than those in Europe, North America and Oceania. It seems that Asian countries have relatively low input resources to produce the current outputs, compared to European and North America countries. Two Middle Eastern countries, Oman and Kuwait, maximized their inputs to produce the current output level. The efficiency score for the United States was .4045; it ranked 41 st, which indicates that its health system efficiency remains at only $40.5 \%$ of its maximum efficient level in light of the given the input-output combination (see appendix 1). While the United States was the second highest-ranking country with respect to both input levels, the contribution of public health expenditure and schooling was not enough to produce better results. This finding is similar to that in the study conducted by Spinks and Hollingsworth (2009) using 1993 and 1997 data.

In the upper-middle-income group, 11 of 45 countries were relatively efficient in maximizing their inputs and thus improved their overall health care system efficiency. The North America region had the highest average efficiency score (.8431), while the Asian region had the lowest average efficiency score (.7184). The bootstrap efficiency scores for Jordan, Suriname, and Turkey were below 50\%. The public health expendi- 
ture of the three poor performers, who ranked at fourth, 11th, and 16th respectively, was considerably high, while their levels of education were lower than the average score of 8.8 years (see appendix 2).

In the lower-middle-income group, the average efficiency scores varied substantially by regions (see appendix 3). North America with average efficiency of .9111 was ranked first, whereas South America with average efficiency of .4923 was ranked last. In total, 11 of the 51 countries were efficient at the maximum level, which indicates that $21.6 \%$ maximized their input resources to produce the current levels of life expectancy and child mortality. The corrected efficiency estimates for this group ranged from .2596 to 1 . The 19 countries had health care scores that fell below .5 . Djibouti, Uzbekistan, and Kiribati, which scored 27.6\%, 27.5\%, and 26\%, respectively, turned out to be poor performers. The average score of Asian countries was middling, but the variation of efficient scores was the highest across the regions.

The low-income group mostly consists of African and Asian countries. Ten out of 32 countries ranked as most efficient compared to other countries in the group. The 17 countries scored below the .5 efficiency level, so a large proportion of the low-income group managed input resources poorly in producing outputs. An interesting observation, however, is that the six low-income Asian countries earned an efficient score of 1 (see appendix 4). This result may be the product of the exceptionally low levels of their inputs. Afghanistan's public health expenditure, for example, was only 3.7\%, and its

average schooling was about .4 years, which is much less than the average schooling of 2.85 years in the low-income group. There were large variations in efficiency scores among African countries, ranging from .1973 to 1.

\section{DISCUSSION AND CONCLUSIONS}

Countries have made substantial efforts to improve the quality of health care delivery to produce better health outputs. This study, however, found that most countries across the four income groups were inefficient to maximize their inputs at the given output level. The average efficiency scores for countries in the high- and the upper-middleincome groups are .7380 and .7732 , respectively, so there is still room for improvement in maximizing the input resources of health care systems. The variations of efficiency scores in the lower-middle- and the low-income countries were larger than those in the high-income countries.

No consensus as to which input and output variables should be included in a DEA model has been made among researchers in the public health care field, so this study conducted the sensitivity test to assure the robustness of the full model specification. 
As a result of the sensitivity test, which measured the variations of the mean efficiency scores for each model, the magnitude of efficiency changes in the full specification is neither overestimated nor underestimated. This means that homogeneity of each group is properly controlled and that the reversal of the mortality rate of children under five is adequately specified for cross-country comparisons.

The results indicate that the efficiency of health care systems is different by geographical regions. In the high-income group, countries in Asia performed more efficiently than those in other regions, while North America countries largely underperformed in the use of their inputs. Interestingly, African countries in the upper-middle-income group used their inputs efficiently at the given output level $\pi$ enoteddl ional level. In both upper- and lower-middle-income groups, Asia countries fared in the middle. Notably, six out of seven Asian countries in the low income group were evaluated as efficient performers. This result may be explained by the fact that their input levels are substantially low, while their output levels are high compared to other regions.

While this study thoroughly examined the productivity of health care systems in 170 countries and has concluded that inefficient countries can improve health care delivery by comparing their operating practices to those of efficient countries, there are some limitations to this study. First, the use of different combinations of inputs and outputs may change the results. While we reduced the variability using the bootstrapping method, further fluctuations in the rankings may occur when different sets of input and output variables are used. González et al. (2010), for example, used the disabilityadjusted life years measured in the years of life lost due to both premature mortality and disability instead of infant mortality, since it may carry information on quality of extended life years. In regard to health expenditure, some studies (e.g., Hollingsworth \& Wildman 2003; Greene, 2004) have used health expenditure per capita, as that measure counts both public and private health care expenditure. Furthermore, prior research noted that a country's production function may be dependent on environmental constraints, such as demographic structure and economic conditions (Jacobs et al., 2006). Future research should take those input and output variables as well as environmental factors into account in constructing DEA bootstrap models, although techniques to incorporate environmental variables are persistently debated in terms of specification issues. Second, a heterogeneity issue in our DEA model may still persist, even though this study clustered 170 countries by the four income-based groups to ensure the minimum homogeneity needed for DEA. Characteristics of health care environments at a country level rather than income levels have more of an impact in differentiating between countries in terms of health status (Greene, 2004). For future research, countyspecific health factors should be applied to capture residual heterogeneity with given input and output levels. 
In regard to the implications for public health policy, countries with inefficient health care delivery should develop feasible health care strategies by replicating best practices within their regional peer groups. Increasing public expenditure on health care across the four groups, for instance, may not be always produce desirable results directly, as other studies have asserted a weak link between public spending and health status (e.g., Filmer \& Pritchett, 1999; Musgrove, 1996; Rajkumar \& Swaroop, 2008). While this study does not attempt to find the causes of efficiency differences between high-performing and low-performing countries, future research may conduct a two-stage DEA model to explain these differences across countries, considering various healthrelevant factors.

\section{REFERENCES}

Adam, A., Delis, M, \& Kammas, P. 2011 Public sector efficiency: Leveling the playing field between OECD countries. Public Choice, 146(1/2): 163-183.

Afonso A., \& St Aubyn, M. 2005. Non-parametric approaches to education and health efficiency in OECD countries. Journal of Applied Economics, 8(2): 227-246.

Alexander, C. A., Busch, G., \& Stringer, K. 2003. Implementing and interpreting a data envelopment analysis model to assess the efficiency of health systems in developing countries. IMA Journal of Management Mathematics, 14(1): 49-63.

Bahat, V. N. 2005. Institutional arrangements and efficiency of health care delivery systems. European Journal of Health Economics, 6(3): 215-221.

Banker, R. D., Charnes, A., \& Cooper, W. W. 1984. Some models for estimating technical and scale inefficiencies in data envelope analysis. Management Science, 30(9): 1078-1092.

Berger, A., \& Messer, J. 2002. Public financing of health expenditures, insurance, and health outcomes. Applied Economics, 34(17): 2105-2113.

Charnes, A., Cooper, W. W., \& Rhodes, E. 1978. Measuring the efficiency of decision making units. European Journal of Operational Research, 2(6): 429-444.

Charnes, A., Cooper, W. W., \& Rhodes, E.1981. Evaluating program and managerial efficiency: An application of data envelopment analysis to program fellow through. Management Science, 27(6): 668-697.

Charnes, A., Cooper, W. W., Lewin, A. Y., Morey, R. C., \& Rousseau, J. 1985. Sensitivity and stability analysis in DEA. Annals of Operations Research, 2(1): 139-156.

Cooper, W. W., Seiford, L. M., \& Tone, K. 2007. Data envelopment analysis: A comprehensive text with models, applications, references and DEA-Solver Software. 2nd ed. New York: Springer. 
Desai, S., \& Alva, S. 1998. Maternal education and child health: Is there a strong causal relationship? Demography, 35(1): 71-81.

Dyson, R. G., Allen, R., Camanho, A. S., Podinovski, V. V., Sarrico, C. S., \& Shale, E. A. 2001. Pitfalls and protocols in DEA. European Journal of Operational Research, 132(2): 245-259.

Evans, D., Tandon, A., Murray, C., \& Lauer, J. A. 2000. The comparative efficiency of national health systems in producing health: An analysis of 191 countries. World Health Organization, GPE Discussion Paper Series, No. 29, EIP/GPE/ EQC. Retrieved from http://www.who.int/healthinfo/paper29.pdf.

Evans, D., Tandon, A., Murray, C., \& Lauer, J. A. 2001. Comparative efficiency of national health systems: Cross national econometric analysis. British Medical Journal, 323(7308): 307-310.

Färe, R., Grosskopf, S., Lindgren, B., \& Poullier, J. P. 1997. Productivity growth in health-care delivery. Medical Care, 35(4): 354-366.

Farrell, M. J. 1957. The measurement of productive efficiency. Journal of the Royal Statistical Society Series A, 120(3): 369-390.

Filmer, D., \& Pritchett, L. 1999. The effect of household wealth on educational attainment: Evidence from 35 countries. Population and Development Review, 25(1): 85-120.

González, E., Cárcaba, A., \& Ventura, J. 2010. Value efficiency analysis of health systems: Does public financing play a role? Journal of Public Health, 18(4): 337-350.

Greene, W. 2004. Distinguishing between heterogeneity and inefficiency: Stochastic frontier analysis of the world Health Organization's panel data on national health care systems. Health Economics, 13(10): 959-980.

Greene, W. 2007. LIMDEP Version 9.0: Reference Guide. Plainview: Econometric Software, Inc.

Grosskopf, S., Self, S., \& Zaim, O. 2006. Estimating the efficiency of the system of healthcare financing in achieving better health. Applied Economics, 38(13): 1477-1488.

Grossman, M., \& Kaestner, R. 2004. The effects of education on health. In J. R. Behrman, \& N. Stacey (eds.), The social benefits of education (pp. 69-113). Ann Arbor: University of Michigan Press.

Grubaugh, S. G., \& Santerre, R. E. 1994. Comparing the performance of health care systems: An alternative approach. Southern Economics Journal, 60(4): 1030-1042.

Hollingsworth, B. 2008. The measurement of efficiency and productivity of health care delivery. Health Economics, 17(10): 1107-1128.

Hollingsworth, B., \& Wildman, J. 2003. The efficiency of health production: Re-estimating the WHO panel data using parametric and non-parametric approaches to 
provide additional information. Health Economics, 12(6): 493-504.

Jacobs, R., Smith, P. C., \& Street, A. 2006. Measuring efficiency in health care: Analytic techniques and health policy. New York: Cambridge University Press.

Jung, K. 2003. Comparative analysis of health care systems in three developed countries: Germany, Sweden and the United States. Korean Journal of Policy Studies, 17(2): 27-48.

Keeney, R., \& Raiffa, H. 1993. Decisions with multiple objectives: Preferences and value tradeoffs. New York: Cambridge University Press.

Lewis, H. F., \& Sexton, T. R. 2004. Data envelopment analysis with reverse inputs and outputs. Journal of Productive Analysis, 21(2): 113-132.

Lovell, C. A. K. 1993. Production frontiers and productive efficiency. In H. O. Fried, C. A. K. Lovell, \& S. Schmidt (eds.), The measurement of productive efficiency: Techniques and applications (pp. 3-67). New York: Oxford University Press.

Musgrove, P. 1996. Public and private roles in health: Theory and financing patterns. Health, Nutrition, and Population discussion paper. Washington, DC: World Bank.

Ozbek, M. E., de la Garza, J. M., \& Triantis, K. 2010. Efficiency measurement of bridge maintenance using data envelopment analysis. Journal of Infrastructure Systems, 16(1): 31-39.

Rajkumar, A. S., \& Swaroop, V. 2008. Public spending and outcomes: Does governance matter? Journal of Development Economics, 86(1): 96-111.

Rehm, J., Greenfield, T., \& Rogers, J. 2001. Average volume of alcohol consumption, patterns of drinking, and all-cause mortality: Results from the US national alcohol survey. American Journal of Epidemiology, 153(1): 64-71.

Retzlaff-Roberts, D., Chang, C. F., \& Rubin, R. M. 2004. Technical efficiency in the use of health care resources: A comparison of OECD countries. Health Policy, 69(1): 55-72.

Richards, R. C. 2003. Setting benchmarks and evaluating balanced scorecards with data envelopment analysis. Benchmarking: An International Journal, 10(3): 226-245.

Scheel, H. 2001. Undesirable outputs in efficiency valuations. European Journal of Operational Research, 132(2): 400-410.

Schoen, C., Osborn, R., Doty, M. M., Bishop, M., Peugh, J., \& Murukutla, N. 2007. Toward higher-performance health systems: Adult's health care experiences in seven countries, 2007. Health Affairs, 26(6): w717-w734.

Seiford, L. M., \& Zhu, J. 1998a. Stability regions for maintain efficiency in data envelopment analysis. European Journal of Operational Research, 108(1): 127-139.

Seiford, L. M., \& Zhu, J. 1998b. Sensitivity analysis of DEA models for simultaneous changes in all the data. Journal of the Operational Research Society, 49(10): 
1060-1071.

Sen, A. K. 1999. Development as freedom. New York: Knopf.

Simar, L., \& Wilson, P. W. 1998. Sensitivity analysis of efficiency scores: How to bootstrap in nonparametric frontier models. Management Science, 44(1): 49-61.

Simar, L., \& Wilson, P. W. 2000. Statistical inference in nonparametric frontier models: The state of the art. Journal of Productivity Analysis, 13(1): 49-78.

Spinks, J., \& Hollingsworth, B. 2005. Health production and the socioeconomic determinants of health in OECD countries: The use of efficiency models. Centre for Health Economics Working Paper. Melbourne, Australia: Centre for Health Economics.

Spinks, J., \& Hollingsworth, B. 2009. Cross-country comparisons of technical efficiency of health production: A demonstration of pitfalls. Applied Economics, 41(4): 417-427.

Thanassoulis, E. 2001. Introduction to the theory and application of data envelopment analysis: A foundation text with integrated software. Norwell: Kluwer.

Thanassoulis, E., Portela, M. C. S., \& Despić, O. 2008. Data envelopment analysis: The mathematical programming approach to efficiency analysis. In H. O. Fried, C. A. K. Lovell, \& S. Schmidt (eds.), The measurement of productive efficiency: Techniques and applications (pp. 251-420). New York: Oxford University Press.

Thompson, R. G., Dharmapala, P. S., Diaz, J., Gonzalez-Lima, M. D., \& Thrall, R. M. 1996. DEA multiplier analytic center sensitivity analysis with an illustrative application to independent oil companies. Annals of Operations Research, 66(1-4): 163-180.

Valdmanis, V. 1992. Sensitivity analysis for DEA models: An empirical example using public vs. NFP hospitals. Journal of Public Economics, 48(2): 185-205.

Wilkinson, R. G. 1992. Income distribution and life expectancy. British Medical Journal, 304(6820): 165-168.

World Health Organization. 2000. Health systems: Improving performance. World Health Report 2000. Geneva: World Health Organization. 
Appendix 1. Bootstrap of Corrected Efficiency Scores for High Income Countries

\begin{tabular}{|c|c|c|c|c|c|}
\hline Region & Country & $\begin{array}{l}\text { Full } \\
\text { Model }\end{array}$ & $\begin{array}{l}\text { Life } \\
\text { Expectancy } \\
\text { Excluded }\end{array}$ & $\begin{array}{c}\text { Child } \\
\text { Mortality } \\
\text { Excluded }\end{array}$ & $\begin{array}{c}\text { Rank by } \\
\text { Full } \\
\text { Model }\end{array}$ \\
\hline Africa & Equatorial Guinea & 1 & 1 & 1 & 1 \\
\hline Asia & $\begin{array}{l}\text { Bahrain } \\
\text { Japan } \\
\text { Korea, Rep. } \\
\text { Kuwait } \\
\text { Oman } \\
\text { Qatar } \\
\text { Saudi Arabia } \\
\text { Singapore } \\
\text { United Arab Emirates }\end{array}$ & $\begin{array}{r}.5903 \\
1 \\
.7115 \\
1 \\
1 \\
.7242 \\
.9936 \\
1 \\
.7909\end{array}$ & $\begin{array}{r}.5768 \\
.5476 \\
.6772 \\
1 \\
1 \\
.7106 \\
1 \\
1 \\
.7731\end{array}$ & $\begin{array}{r}.5921 \\
1 \\
.7721 \\
1 \\
1 \\
.7812 \\
.9908 \\
1 \\
.7312\end{array}$ & $\begin{array}{r}32 \\
1 \\
21 \\
1 \\
1 \\
20 \\
8 \\
1 \\
14\end{array}$ \\
\hline Europe & $\begin{array}{l}\text { Austria } \\
\text { Belgium } \\
\text { Croatia } \\
\text { Cyprus } \\
\text { Czech Rep. } \\
\text { Denmark } \\
\text { Estonia } \\
\text { Finland } \\
\text { France } \\
\text { Germany } \\
\text { Greece } \\
\text { Hungary } \\
\text { Ireland } \\
\text { Israel } \\
\text { Italy } \\
\text { Luxembourg } \\
\text { Netherlands } \\
\text { Norway } \\
\text { Poland } \\
\text { Portugal } \\
\text { Slovak Rep. } \\
\text { Slovenia } \\
\text { Spain } \\
\text { Sweden } \\
\text { Switzerland } \\
\text { United Kingdom }\end{array}$ & $\begin{array}{r}.5992 \\
.6419 \\
.5369 \\
1 \\
.6971 \\
.6137 \\
.6771 \\
.7593 \\
.6250 \\
.5218 \\
.7474 \\
.7065 \\
.5837 \\
1 \\
.8303 \\
.7455 \\
.5689 \\
.5984 \\
.6378 \\
.7910 \\
.5482 \\
.7617 \\
.8738 \\
.9361 \\
.9195 \\
.5856\end{array}$ & $\begin{array}{r}.5883 \\
.6172 \\
.5347 \\
1 \\
.6736 \\
.6011 \\
.6560 \\
.7476 \\
.5855 \\
.5133 \\
.7398 \\
.6833 \\
.5706 \\
.7446 \\
.6669 \\
.7336 \\
.5617 \\
.5892 \\
.6116 \\
.7900 \\
.5318 \\
.7401 \\
.6649 \\
.7202 \\
.4711 \\
.5578\end{array}$ & $\begin{array}{r}.5895 \\
.6756 \\
.4310 \\
1 \\
.4154 \\
.4916 \\
.4542 \\
.6640 \\
.6449 \\
.5042 \\
.7251 \\
.5428 \\
.5373 \\
1 \\
.8596 \\
.6772 \\
.5952 \\
.6226 \\
.4771 \\
.7253 \\
.3679 \\
.5887 \\
.8902 \\
.9373 \\
.9361 \\
.6149\end{array}$ & $\begin{array}{r}30 \\
26 \\
38 \\
1 \\
23 \\
29 \\
24 \\
16 \\
28 \\
39 \\
17 \\
22 \\
34 \\
1 \\
12 \\
18 \\
35 \\
31 \\
27 \\
13 \\
36 \\
15 \\
11 \\
9 \\
10 \\
33\end{array}$ \\
\hline North America & $\begin{array}{l}\text { Bahamas } \\
\text { Canada } \\
\text { Trinidad and Tobago } \\
\text { United States }\end{array}$ & $\begin{array}{l}.3581 \\
.6718 \\
.5433 \\
.4045\end{array}$ & $\begin{array}{l}.3650 \\
.4899 \\
.5961 \\
.4095\end{array}$ & $\begin{array}{l}.4119 \\
.6923 \\
.5944 \\
.4154\end{array}$ & $\begin{array}{l}42 \\
25 \\
37 \\
41\end{array}$ \\
\hline Oceania & $\begin{array}{l}\text { Australia } \\
\text { New Zealand }\end{array}$ & $\begin{array}{l}.7362 \\
.4961\end{array}$ & $\begin{array}{l}.5189 \\
.4550\end{array}$ & $\begin{array}{l}.7536 \\
.5179\end{array}$ & $\begin{array}{l}19 \\
40\end{array}$ \\
\hline
\end{tabular}


Appendix 2. Bootstrap of Corrected Efficiency Scores for Upper-Middle Income Countries

\begin{tabular}{|c|c|c|c|c|c|}
\hline Region & Country & $\begin{array}{c}\text { Full } \\
\text { Model }\end{array}$ & $\begin{array}{l}\text { Life } \\
\text { Expectancy } \\
\text { Excluded }\end{array}$ & $\begin{array}{c}\text { Child } \\
\text { Mortality } \\
\text { Excluded }\end{array}$ & $\begin{array}{c}\text { Rank by } \\
\text { Full } \\
\text { Model }\end{array}$ \\
\hline Africa & $\begin{array}{l}\text { Algeria } \\
\text { Botswana } \\
\text { Ecuador } \\
\text { Gabon } \\
\text { Mauritius } \\
\text { Namibia } \\
\text { Seychelles } \\
\text { South Africa } \\
\text { Tunisia }\end{array}$ & $\begin{array}{r}.8385 \\
.6521 \\
1 \\
.9098 \\
.7799 \\
.6407 \\
.5802 \\
.8400 \\
1\end{array}$ & $\begin{array}{r}.9510 \\
.9487 \\
.7996 \\
1 \\
.7889 \\
.9395 \\
.5650 \\
1 \\
.6267\end{array}$ & $\begin{array}{r}.8450 \\
.6553 \\
1 \\
.9220 \\
.7731 \\
.6488 \\
.6326 \\
.8504 \\
1\end{array}$ & $\begin{array}{r}18 \\
30 \\
1 \\
14 \\
22 \\
32 \\
39 \\
17 \\
1\end{array}$ \\
\hline Asia & $\begin{array}{l}\text { China } \\
\text { Iran, Islamic Rep. } \\
\text { Jordan } \\
\text { Kazakhstan } \\
\text { Lebanon } \\
\text { Malaysia } \\
\text { Maldives } \\
\text { Thailand }\end{array}$ & $\begin{array}{r}.7703 \\
.7609 \\
.4875 \\
.5153 \\
.5346 \\
1 \\
1 \\
.6786\end{array}$ & $\begin{array}{r}.6550 \\
.9733 \\
.4568 \\
.6319 \\
.5453 \\
1 \\
1 \\
.6812\end{array}$ & $\begin{array}{r}.8037 \\
.7746 \\
.4987 \\
.5341 \\
.5537 \\
1 \\
1 \\
.4919\end{array}$ & $\begin{array}{r}23 \\
24 \\
43 \\
42 \\
41 \\
1 \\
1 \\
28\end{array}$ \\
\hline Europe & $\begin{array}{l}\text { Albania } \\
\text { Azerbaijan } \\
\text { Belarus } \\
\text { Bosnia \& Herzegovina } \\
\text { Bulgaria } \\
\text { Latvia } \\
\text { Lithuania } \\
\text { Macedonia, FYR } \\
\text { Montenegro } \\
\text { Romania } \\
\text { Russian Federation } \\
\text { Serbia } \\
\text { Turkey }\end{array}$ & $\begin{array}{r}1 \\
1 \\
.6984 \\
1 \\
.5870 \\
.6471 \\
.5903 \\
.6960 \\
.6608 \\
.5531 \\
.7161 \\
.8123 \\
.4712\end{array}$ & $\begin{array}{r}.7464 \\
1 \\
.6788 \\
.5570 \\
.5696 \\
.6144 \\
.5711 \\
.5468 \\
.6220 \\
.5499 \\
.6918 \\
.8111 \\
.5045\end{array}$ & $\begin{array}{r}1 \\
1 \\
.5968 \\
.9370 \\
.6123 \\
.6225 \\
.5218 \\
.7332 \\
.6479 \\
.5940 \\
.5851 \\
.5955 \\
.5080\end{array}$ & $\begin{array}{r}1 \\
1 \\
26 \\
1 \\
37 \\
31 \\
34 \\
27 \\
29 \\
40 \\
25 \\
20 \\
44\end{array}$ \\
\hline North America & $\begin{array}{l}\text { Antigua and Barbuda } \\
\text { Costa Rica } \\
\text { Cuba } \\
\text { Dominican Rep. } \\
\text { Jamaica } \\
\text { Mexico } \\
\text { Panama }\end{array}$ & $\begin{array}{r}.5962 \\
1 \\
1 \\
.5822 \\
.8730 \\
.9815 \\
.8690 \\
\end{array}$ & $\begin{array}{r}.5751 \\
.8460 \\
1 \\
.6751 \\
.8775 \\
.5407 \\
.4579 \\
\end{array}$ & $\begin{array}{r}.5352 \\
1 \\
1 \\
.5898 \\
.8791 \\
.9846 \\
.8831 \\
\end{array}$ & $\begin{array}{r}33 \\
1 \\
1 \\
38 \\
15 \\
12 \\
16\end{array}$ \\
\hline South America & $\begin{array}{l}\text { Argentina } \\
\text { Brazil } \\
\text { Chile } \\
\text { Colombia } \\
\text { Peru } \\
\text { Suriname } \\
\text { Uruguay } \\
\text { Venezuela, Rep. }\end{array}$ & $\begin{array}{r}.8152 \\
1 \\
1 \\
.5876 \\
.5879 \\
.4678 \\
.9415 \\
.7957\end{array}$ & $\begin{array}{r}.4514 \\
1 \\
.7873 \\
.4149 \\
.4552 \\
.5230 \\
.4763 \\
.7419\end{array}$ & $\begin{array}{r}.7959 \\
1 \\
1 \\
.6292 \\
.6021 \\
.4825 \\
.9350 \\
.8377\end{array}$ & $\begin{array}{r}19 \\
1 \\
1 \\
36 \\
35 \\
45 \\
13 \\
21\end{array}$ \\
\hline
\end{tabular}


Appendix 3. Bootstrap of Corrected Efficiency Scores for Lower-Middle Income Countries

\begin{tabular}{|c|c|c|c|c|c|}
\hline Region & Country & $\begin{array}{l}\text { Full } \\
\text { Model }\end{array}$ & $\begin{array}{l}\text { Life } \\
\text { Expectancy } \\
\text { Excluded }\end{array}$ & $\begin{array}{l}\text { Child } \\
\text { Mortality } \\
\text { Excluded }\end{array}$ & $\begin{array}{c}\text { Rank by } \\
\text { Full } \\
\text { Model }\end{array}$ \\
\hline Africa & $\begin{array}{l}\text { Angola } \\
\text { Cameroon } \\
\text { Cape Verde } \\
\text { Congo, Rep. } \\
\text { Cote d'Ivoire } \\
\text { Djibouti } \\
\text { Egypt, Arab Rep. } \\
\text { Ghana } \\
\text { Lesotho } \\
\text { Mauritania } \\
\text { Morocco } \\
\text { Nigeria } \\
\text { Sao Tome and Principe } \\
\text { Senegal } \\
\text { Sudan } \\
\text { Swaziland } \\
\text { Zambia }\end{array}$ & $\begin{array}{r}.5449 \\
.5171 \\
1 \\
.6755 \\
.8710 \\
.2762 \\
.8411 \\
.3950 \\
.4883 \\
.7778 \\
1 \\
.6776 \\
.3228 \\
.3315 \\
.3790 \\
.4350 \\
.4246\end{array}$ & $\begin{array}{r}.9548 \\
.8421 \\
1 \\
.9690 \\
1.0000 \\
.2952 \\
.8672 \\
.4065 \\
.5385 \\
1 \\
1 \\
.9981 \\
.2419 \\
.4018 \\
.5083 \\
.4387 \\
.6231\end{array}$ & $\begin{array}{l}.5380 \\
.5155 \\
.8787 \\
.6840 \\
.8670 \\
.2647 \\
.7080 \\
.4230 \\
.4973 \\
.7793 \\
1 \\
.6799 \\
.3391 \\
.3132 \\
.3804 \\
.4618 \\
.4240\end{array}$ & $\begin{array}{r}29 \\
31 \\
1 \\
26 \\
15 \\
49 \\
16 \\
39 \\
34 \\
18 \\
1 \\
25 \\
48 \\
47 \\
43 \\
36 \\
37\end{array}$ \\
\hline Asia & $\begin{array}{l}\text { Armenia } \\
\text { Georgia } \\
\text { India } \\
\text { Indonesia } \\
\text { Iraq } \\
\text { Kiribati } \\
\text { Lao PDR } \\
\text { Mongolia } \\
\text { Pakistan } \\
\text { Papua New Guinea } \\
\text { Philippines } \\
\text { Sri Lanka } \\
\text { Syrian Arab Rep. } \\
\text { Timor-Leste } \\
\text { Turkmenistan } \\
\text { Uzbekistan } \\
\text { Vietnam } \\
\text { Yemen, Rep. }\end{array}$ & $\begin{array}{r}.6950 \\
.5016 \\
.7691 \\
.6599 \\
1 \\
.2596 \\
.9325 \\
.4072 \\
1 \\
.3860 \\
.6826 \\
1 \\
1 \\
.4934 \\
.3720 \\
.2746 \\
.9999 \\
1 \\
\end{array}$ & $\begin{array}{r}.6272 \\
.4921 \\
.8670 \\
.5269 \\
1 \\
.2570 \\
.9415 \\
.4125 \\
1 \\
.4021 \\
.5423 \\
1 \\
1 \\
.4771 \\
.3809 \\
.2817 \\
.6725 \\
1 \\
\end{array}$ & $\begin{array}{r}.7555 \\
.5498 \\
.8013 \\
.6918 \\
1 \\
.2851 \\
.9346 \\
.2905 \\
1 \\
.4441 \\
.7100 \\
.7288 \\
1 \\
.2578 \\
.4025 \\
.2699 \\
1 \\
1 \\
\end{array}$ & $\begin{array}{r}23 \\
32 \\
19 \\
27 \\
1 \\
51 \\
14 \\
38 \\
1 \\
41 \\
24 \\
1 \\
1 \\
33 \\
44 \\
50 \\
12 \\
1 \\
\end{array}$ \\
\hline Europe & $\begin{array}{l}\text { Moldova } \\
\text { Ukraine }\end{array}$ & $\begin{array}{r}.5218 \\
1\end{array}$ & $\begin{array}{r}.5231 \\
1\end{array}$ & $\begin{array}{l}.2628 \\
.3499\end{array}$ & $\begin{array}{r}30 \\
1\end{array}$ \\
\hline North America & $\begin{array}{l}\text { Belize } \\
\text { El Salvador } \\
\text { Guatemala } \\
\text { Honduras } \\
\text { Nicaragua }\end{array}$ & $\begin{array}{r}1 \\
.9931 \\
.8035 \\
.7588 \\
1 \\
\end{array}$ & $\begin{array}{l}.7098 \\
.9750 \\
.7889 \\
.7410 \\
.8820 \\
\end{array}$ & $\begin{array}{r}1 \\
.5838 \\
.7899 \\
.7644 \\
1 \\
\end{array}$ & $\begin{array}{r}1 \\
13 \\
17 \\
21 \\
1 \\
\end{array}$ \\
\hline Oceania & $\begin{array}{l}\text { Fiji } \\
\text { Marshall Islands } \\
\text { Samoa } \\
\text { Solomon Islands } \\
\text { Tonga } \\
\text { Vanuatu }\end{array}$ & $\begin{array}{r}.5690 \\
.3913 \\
.3685 \\
.7634 \\
.4847 \\
1 \\
\end{array}$ & $\begin{array}{r}.5809 \\
.3874 \\
.3729 \\
.7644 \\
.4868 \\
1\end{array}$ & $\begin{array}{l}.3561 \\
.2872 \\
.3727 \\
.2997 \\
.3937 \\
.5133 \\
\end{array}$ & $\begin{array}{r}28 \\
40 \\
46 \\
20 \\
35 \\
1\end{array}$ \\
\hline South America & $\begin{array}{l}\text { Bolivia } \\
\text { Guyana } \\
\text { Paraguay }\end{array}$ & $\begin{array}{l}.3816 \\
.3694 \\
.7260\end{array}$ & $\begin{array}{l}.4067 \\
.3687 \\
.7265\end{array}$ & $\begin{array}{l}.4056 \\
.2602 \\
.5808\end{array}$ & $\begin{array}{l}42 \\
45 \\
22\end{array}$ \\
\hline
\end{tabular}


Appendix 4. Bootstrap of Corrected Efficiency Scores for Low Income Countries

\begin{tabular}{|c|c|c|c|c|c|}
\hline Region & Country & $\begin{array}{c}\text { Full } \\
\text { Model }\end{array}$ & $\begin{array}{c}\text { Life } \\
\text { Expectancy } \\
\text { Excluded }\end{array}$ & $\begin{array}{l}\text { Child } \\
\text { Mortality } \\
\text { Excluded }\end{array}$ & $\begin{array}{c}\text { Rank by } \\
\text { Full } \\
\text { Model }\end{array}$ \\
\hline Africa & $\begin{array}{l}\text { Benin } \\
\text { Burkina Faso } \\
\text { Burundi } \\
\text { Central African Rep. } \\
\text { Chad } \\
\text { Comoros } \\
\text { Congo, Dem. Rep. } \\
\text { Eritrea } \\
\text { Ethiopia } \\
\text { Gambia } \\
\text { Guinea } \\
\text { Guinea-Bissau } \\
\text { Kenya } \\
\text { Liberia } \\
\text { Madagascar } \\
\text { Malawi } \\
\text { Mali } \\
\text { Mozambique } \\
\text { Niger } \\
\text { Rwanda } \\
\text { Sierra Leone } \\
\text { Tanzania } \\
\text { Togo } \\
\text { Uganda }\end{array}$ & $\begin{array}{r}.6990 \\
.8036 \\
.3299 \\
.3228 \\
.7081 \\
1 \\
.1973 \\
1 \\
.9182 \\
.4904 \\
1 \\
.8275 \\
.3431 \\
.4204 \\
.3099 \\
.3542 \\
.6593 \\
.3926 \\
1 \\
.3377 \\
.7424 \\
.2707 \\
.7546 \\
.2983\end{array}$ & $\begin{array}{r}.6672 \\
1 \\
.4899 \\
.4920 \\
1 \\
.6036 \\
.3690 \\
1 \\
.9465 \\
.5224 \\
1 \\
1 \\
.3809 \\
.3808 \\
.3222 \\
.4052 \\
.9333 \\
.5001 \\
1 \\
.3591 \\
1 \\
.3025 \\
.6057 \\
.3776\end{array}$ & $\begin{array}{r}.8273 \\
.9219 \\
.3190 \\
.3146 \\
.7066 \\
1 \\
.2033 \\
1 \\
.9828 \\
.4898 \\
1 \\
.8449 \\
.3444 \\
.5490 \\
.3572 \\
.3079 \\
.6918 \\
.2927 \\
1 \\
.2194 \\
.7523 \\
.2248 \\
.8510 \\
.3013\end{array}$ & $\begin{array}{r}18 \\
14 \\
28 \\
29 \\
17 \\
1 \\
33 \\
1 \\
12 \\
21 \\
1 \\
13 \\
26 \\
23 \\
30 \\
25 \\
19 \\
24 \\
1 \\
27 \\
16 \\
32 \\
15 \\
31\end{array}$ \\
\hline Asia & $\begin{array}{l}\text { Afghanistan } \\
\text { Bangladesh } \\
\text { Cambodia } \\
\text { Kyrgyz Rep. } \\
\text { Myanmar } \\
\text { Nepal } \\
\text { Tajikistan }\end{array}$ & $\begin{array}{r}1 \\
1 \\
.4985 \\
1 \\
1 \\
1 \\
1\end{array}$ & $\begin{array}{r}1 \\
.5884 \\
.4670 \\
1 \\
1 \\
1 \\
.1926\end{array}$ & $\begin{array}{r}1 \\
1 \\
.5843 \\
1 \\
1 \\
1 \\
1\end{array}$ & $\begin{array}{r}1 \\
1 \\
20 \\
1 \\
1 \\
1 \\
1\end{array}$ \\
\hline North America & Haiti & .4703 & .4399 & .5512 & 22 \\
\hline
\end{tabular}

